\title{
A Single Amino Acid Substitution (Cys249Trp) in Crb1 Causes Retinal Degeneration and Deregulates Expression of Pituitary Tumor Transforming Gene Pttg1
}

\author{
Serge A. van de Pavert, ${ }_{1}^{1}$ Jan Meuleman, ${ }_{1}^{1}$ Anna Malysheva, ${ }^{1}$ Wendy M. Aartsen, ${ }^{1}$ Inge Versteeg, ${ }^{1}$ Felix Tonagel, ${ }^{4}$ \\ Willem Kamphuis, ${ }^{2}$ Chris J. McCabe, ${ }^{3}$ Mathias W. Seeliger, ${ }^{4}$ and Jan Wijnholds ${ }^{1}$ \\ Departments of ${ }^{1}$ Neuromedical Genetics and ${ }^{2}$ Molecular Ophthalmogenetics, The Netherlands Institute for Neuroscience, Royal Netherlands Academy of \\ Arts and Sciences, 1105 BA Amsterdam, The Netherlands, ${ }^{3}$ Division of Medical Sciences, Institute for Biomedical Research, University of Birmingham, \\ Birmingham B15 2TH, United Kingdom, and ${ }^{2}$ Retinal Electrodiagnostics Research Group, Department of Ophthalmology II, University of Tübingen, \\ D-72076 Tübingen, Germany
}

Different mutations in the human Crumbs homolog-1 (CRB1) gene cause a variety of retinal dystrophies, such as Leber congenital amaurosis, early onset retinitis pigmentosa (e.g., RP12), RP with Coats-like exudative vasculopathy, and pigmented paravenous retinochoroidal atrophy. Loss of Crb1 leads to displaced photoreceptors and focal degeneration of all neural layers attributable to loss of adhesion between photoreceptors and Müller glia cells. To gain insight into genotype-phenotype relationship, we generated $\mathrm{Crb1}{ }^{\mathrm{C} 249 \mathrm{~W}}$ mice that harbor an amino acid substitution (Cys249Trp) in the extracellular sixth calcium-binding epidermal growth factor domain of Crb1. Our analysis showed that $\mathrm{Crb}^{\mathrm{C} 249 \mathrm{~W}}$ as wild-type protein trafficked to the subapical region adjacent to adherens junctions at the outer limiting membrane (OLM). Hence, these data suggest correct trafficking of the corresponding mutant CRB1 in RP12 patients. $\mathrm{Crb1}{ }^{\mathrm{C} 249 \mathrm{~W}}$ mice showed loss of photoreceptors in the retina, relatively late compared with mice lacking Crb1. Scanning laser ophthalmoscopy revealed autofluorescent dots that presumably represent layer abnormalities after OLM disturbance. Gene expression analyses revealed lower levels of pituitary tumor transforming gene 1 (Pttg1) transcripts in $\mathrm{Crb1}^{\mathrm{C} 249 \mathrm{~W} /-}$ knock-in and Crb1 ${ }^{-/-}$knock-out compared with control retinas. Exposure to white light decreased levels of Pttg1 in Crb1 mutant retinas. We hypothesize deregulation of Pttg1 expression attributable to a C249W substitution in the extracellular domain of Crb1.

Key words: adhesion; blindness; retinal degeneration; knock-out mice; mutant; retina; photoreceptors; retinitis pigmentosa (RP); Leber congenital amaurosis (LCA); Müller glia cells

\section{Introduction}

Inherited retinal degenerations often lead to partial or even complete loss of vision. More than 114 retinal disease genes have been identified and linked to eye diseases, such as Leber congenital amaurosis (LCA), retinitis pigmentosa (RP), and other retinopathies (Retnet; www.sph.uth.tmc.edu/retnet/home.htm). Mutations in Crumbs homolog 1 (CRB1) give rise to different phenotypes, such as LCA or early onset RP, such as RP type 12 (RP12).

Received Aug. 11, 2006; revised Nov. 16, 2006; accepted Nov. 19, 2006.

This work was supported by Deutsche Forschungsgemeinschaft (M.W.S.), ZonMW-Nederlandse Organisatie voor Wetenschappelijk Onderzoek Grant 912-02-018 (J.W.), and European Community Grant QLG3-CT-2002-01266 (J.W.). We thank the following: M. Cozijnsen for morula aggregations; R. M. Vos for excellent technical assistance; S van Soest and A. A. B. Bergen for microarray facilities and their continuous interest in this project; $P$. Krimpenfort for the pBS-IoxP-hygro-IoxP vector; P. Rashbass for anti-Crb2; A. Le Bivic for anti-Patj; S. Kakar for anti-Pttg1; J. van der Meulen for the statistical analysis; $T$. van den Berg for light spectrum analysis; T. Gorgels for the light-experiment equipment; B. Nunes-Cardozo for assistance with the CLSM; A. A. Put for the artwork; and A. van Rossum, A. Kantardzhieva, F. Dijk, and P.T.V.M. de Jong for discussions and/or critical reading of this manuscript.

Correspondence should be addressed to Dr. J. Wijnholds, The Netherlands Institute for Neuroscience, Meibergdreef 47, 1105 BA Amsterdam, The Netherlands. E-mail: j.wijnholds@nin.knaw.nl.

S. A. van de Pavert's present address: Department of Molecular Cell Biology and Immunology, Vrije Universiteit Medical Center, van der Boechorststraat 7, 1081 BT Amsterdam, The Netherlands.

D01:10.1523/JNEUROSCI.3496-06.2007

Copyright $\odot 2007$ Society for Neuroscience $\quad$ 0270-6474/07/270564-10\$15.00/0
LCA results in severe loss of vision at birth as demonstrated by loss of electrical activity measured by electroretinography (ERG). RP primarily affects the rod photoreceptors and results in night blindness with progressive loss of vision from the periphery to the center of the retina.

Human CRB1 is a 1406 amino acids transmembrane protein with 19 epidermal growth factor (EGF) domains, three laminin A G-like domains, a single transmembrane domain, and a 37 amino acids intracellular domain. Mouse Crb1 is one amino acid shorter attributable to loss of codon 55 in the first EGF domain but has a very similar structure as human CRB1 (den Hollander et al., 2002).

$\mathrm{Crb1}^{-1-}$ knock-out mice do not synthesize Crb1 protein and develop focal retinal disorganization of the photoreceptor layer, such as large half rosettes of photoreceptors (van de Pavert et al., 2004). The phenotype is attributable to loss of maintenance of adhesion between photoreceptors and Müller glia cells. The affected regions undergo light-accelerated focal degeneration of all retinal layers except the ganglion cell layer.

It has been hypothesized that mutations that lead to two CRB1 null alleles result in LCA, whereas more subtle mutations result in milder phenotypes, such as RP (Cremers et al., 2002; den Hol- 
Table 1. Oligonucleotides used for the generation of $\mathrm{Crb1}{ }^{\mathrm{C249W} /-}$ mice

\begin{tabular}{|c|c|}
\hline JW12 & 5'-AGCAAAATCCAATTCACG-3' \\
\hline JW56 & 5'-GATCGGGCCCATCGATCAATTAGAGTAGAGGAGGAG-3' \\
\hline JW57 & $5^{\prime}$-GGAATCCAGGTGCCCAGTCACAGG-3' \\
\hline JW58 & $5^{\prime}$-CCTGTGACTGGGCACCTGGATTCC $-3^{\prime}$ \\
\hline JW59 & 5'-GACCTCCATGGAGACACGGCTG-3' \\
\hline JW70 & $5^{\prime}$-GGAAATGACAGATGTTGCAGGGAC-3' \\
\hline JW73 & 5'-AGCGGTCGACTAGAGCTTGCGG-3' \\
\hline JW74 & 5'-CATAGGCGTGAACTGTGAGTTGG-3' \\
\hline JW76 & $5^{\prime}$-CTCCATGGAGACACGGCTGAC-3' \\
\hline JW82 & 5'-ATCCCCCGGGCTGCAGGAATTCCG-3' \\
\hline JW83 & 5'-CGAAGTTATTAGGTCCCTCGAAGC-3' \\
\hline JW105 & 5'-AAAACCTGGACCAGAAGCGC-3' \\
\hline JW123 & $5^{\prime}$-GCTGTGTAGAAGTACTCGCCG-3' \\
\hline JW253 & 5'-GCACCCTTTCTTCACACCCACTTG-3' \\
\hline
\end{tabular}

lander et al., 2004). However, genetic background can suppress severe retinal CRB1 phenotypes (Mehalow et al., 2003), and the hypothesis that different mutations in Crb1 on the same genetic background lead to different phenotypes has not been verified.

Here, we generated $\mathrm{Crb1}^{\mathrm{C} 249 \mathrm{~W}}$ mutant mice as a mouse model for RP12 patients that harbor C250W mutations and analyzed the retinal phenotype. This point mutation causes a change from a cysteine into a tryptophan in the extracellular sixth EGF domain. The six cysteines in EGF domains are required for disulfide bridging, and substitution of these amino acids are likely to result in structural changes in and loss of function of the EGF domain. Whereas the intracellular domain of Crb1 is known to bind several membrane-associated guanylate kinase (MAGUK) and multiple PDZ [postsynaptic density-95/Discs large/zona occludens-1 (ZO-1)] proteins, associations of proteins with the extracellular domain are not known. Here, we suggest a function for the extracellular domain of Crb1 in regulating pituitary tumor transforming gene 1 (Pttg1) transcript levels. In addition, we show that mutant Crb $1{ }^{\mathrm{C} 249 \mathrm{~W}}$ protein is produced and localized correctly to the subapical region (SAR) adjacent to adherens junctions and has retained residual Crb1 activity in maintaining adhesion between photoreceptors and Müller glia cells but lost the capacity to regulate Pttg1. We show that different mutations in the Crb1 gene on the same genetic background result in phenotypes of different severity.

\section{Materials and Methods}

Generation of $\mathrm{Crb} 1{ }^{\mathrm{C} 249 \mathrm{~W} /-}$ mice. A cDNA fragment containing exons 2 and 3 of $C r b 1$ was used to isolate clone 44 from a $\lambda$ EMBL3 genomic 129/Ola DNA phage library. The 3 '-arm vector containing a point mutation (TGT to TGG) in codon 249 of exon 3 was generated by PCR. Primers JW56 in intron 2 and JW57 in exon 3, primers JW58 and JW59 in exon 3 (Table 1), and a combination of primers JW56 and JW59 were used to generate a C249W mutation in mouse Crb1, a model for the C250W mutation in human CRB1. The $3^{\prime}$-arm of the targeting vector was generated by ligating a pGEM5 vector containing the $314 \mathrm{bp}$ ApaI/

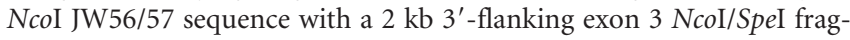
ment from $\lambda$ EMBL3 clone 44 . The $2.3 \mathrm{~kb} \mathrm{3'}$-arm was subcloned as (blunted-ApaI)/NotI fragment into (blunted-ClaI)/NotI sites of pBSloxP-hygro-loxP-(X/B) containing a hygromycin resistance gene driven by the mouse phosphoglycerate kinase promoter. A $5.3 \mathrm{~kb} 5^{\prime}$-targeting arm was subcloned as XhoI/(blunted-ApaI) fragment into the XhoI/ (blunted-XbaI) sites of pBS-loxP-hygro-loxP containing the $3^{\prime}$ targeting arm. Correct targeting deleted $3.6 \mathrm{~kb}$ of intron 2, inserted the floxed hygro cassette in intron 2, and replaced the wild-type exon 3 with an exon 3 harboring the $\mathrm{C} 249 \mathrm{~W}$ mutation. Correct homologous recombination in embryonic day 14 mouse embryonic stem (ES) cells was verified by long-template PCR of a mutant-specific $2.7 \mathrm{~kb}$ fragment using primer JW73 in the hygro cassette and JW70 in intron 3 abutting the $3^{\prime}$-flank of the targeting vector. The recombination efficiency for the first step was $18 \%$. The floxed hygro cassette was removed by electroporation of Cre recombinase (pOG321) and puromycin resistance (pPGK-puro) expression plasmids into independent Crb1 $1^{\text {flox-hygro-C249W/+ }}$ ES cell clones. Correct removal of the floxed hygro cassette was verified by PCR of a $400 \mathrm{bp}$ fragment using primer JW82 adjacent to the first loxP site and JW76 in exon 3. The recombination efficiency for the second step was $64 \%$. Three $\mathrm{Crb1}^{\mathrm{C} 249 \mathrm{~W} /+}$ ES clones with normal karyotype were aggregated with C57BL/6 mouse morulas, of which two gave germ-line transmission. The mutant $\mathrm{Crb}^{\mathrm{C249W}}$ allele in heterozygote mice was analyzed by long-template PCR. A mutant-specific $2.6 \mathrm{~kb}$ fragment containing part of the hygro cassette, the complete $2.3 \mathrm{~kb} 3$ '-targeting arm, and a region adjacent to the targeting arm was amplified using primer JW83 and JW70 in intron 3 abutting the $3^{\prime}$-flank of the targeting vector. JW83 is specific for the second lox $\mathrm{P}$ site but recognizes the single lox $\mathrm{P}$ site in the mutant allele. A mutant-specific $0.7 \mathrm{~kb}$ fragment and a wild-typespecific $4.2 \mathrm{~kb}$ fragment, containing a part of the $5^{\prime}$-flanking targeting arm, the single lox $\mathrm{P}$ site, or $3.6 \mathrm{~kb}$ wild-type intron 2 sequence and a part of the $3^{\prime}$-flanking arm, was amplified using primer JW253 in the $5^{\prime}$-arm and JW12 in intron 3. Cre recombinase and puromycine resistance gene markers were used to test for absence of pOG321 and pPGK-puro sequences. Unexpected, crossing of $\mathrm{Crb1}^{\mathrm{C} 249 \mathrm{~W} / \mathrm{C} 249 \mathrm{C}}$ heterozygote mice from both clones yielded 68 offspring with 78\% wild-type, 22\% heterozygote, and $0 \%$ of homozygote mice. Crossing of heterozygous mice backcrossed eight times onto C57BL/6 did also not result in homozygous Crb1 $1^{C 249 W / C 249 W}$ mice. Homozygous $\mathrm{Crb}^{-1-}$ knock-out mice were viable (van de Pavert et al., 2004), similar to homozygous $C R B 1^{C 250 W / C 250 W}$ patients (den Hollander et al., 2004); therefore, it was unlikely that the $\mathrm{Crb1} 1^{\mathrm{C} 249 \mathrm{~W}}$ mutation caused lethality. We suggest that additional mutations were introduced in the $C r b 1^{C 249 W}$ ES cells during the two selection rounds for recombination events or that homologous recombination deleted an essential DNA region in intron 2. For the analysis of the $\mathrm{Crbl}^{\mathrm{C249W}}$ allele, we used mutant $\mathrm{Crb1}^{\mathrm{C} 249 \mathrm{~W} /-}$ and control $\mathrm{Crb1} 1^{\mathrm{C} 249 \mathrm{C} /-}$ from a cross of $\mathrm{Crb1}^{-1-}$ with $\mathrm{Crb1} 1^{\mathrm{C} 249 \mathrm{~W} / \mathrm{C} 249 \mathrm{C}}$ mice. $\mathrm{Crb1}^{-1-}$ mice harbor a deletion of the promoter region and exon 1 (van de Pavert et al., 2004) and do not express Crb1. Both mouse stocks (Crb1 ${ }^{\mathrm{C} 249 \mathrm{~W} /-}$ and

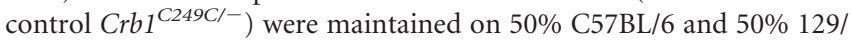
Ola genetic background and kept on a $12 \mathrm{~h}$ dark/dimmed light (100 lux) cycle.

For PCR genotype analysis, the $\mathrm{Crb1}^{-}$knock-out allele (with deleted exon 1 but wild-type exon 3 ) was detected by PCR using forward primer JW123 in the hygro cassette and reverse primer JW105 in intron 1. This primer pair amplifies a $470 \mathrm{bp}$ fragment from intron 1 in the $\mathrm{Crbl}^{-}$null allele. Specific amplification of the mutant exon 3 allele was done by using forward primer JW83 in the single loxP site in intron 2 with reverse primer JW12 in intron 3. This primer pair amplifies a $450 \mathrm{bp}$ fragment from the $C r b 1^{C 249 W}$ allele. For sequencing, both the wild-type and mutant exon 3 alleles were amplified using forward primer JW74 in exon 3 with reverse primer JW12. These primer pairs amplify a $254 \mathrm{bp}$ fragment.

Animals. All animals were treated according to guidelines established at the institutions in which the experiments were performed and approved by the Animal Care and Use Committee. Before the start of the light exposure, mice were maintained in a $12 \mathrm{~h}$ dark/dimmed light (100 lux) cycle. After a $12 \mathrm{~h}$ dark period, mice were immediately and for $72 \mathrm{~h}$ continuously exposed to 3000 lux of diffuse white fluorescent light [TLD$18 \mathrm{~W} / 33$ tubes (Philips, Aachen, Germany); 350-700 nm] without pupillary dilation. Immediately after light exposure, the eyes were marked for orientation and thereafter enucleated.

Morphological and immunohistochemical analysis. Eyes from the animals were enucleated, and, subsequently, retinas were snap-frozen or the anterior segment was fixed for cryosectioning, paraffin sectioning, or 3 $\mu \mathrm{m}$ sectioning in Technovit 7100 (Kultzer, Wehrheim, Germany).

After 30 min fixation at room temperature (RT) with 4\% paraformaldehyde in PBS, the mouse eyecups were cryoprotected with sucrose in PBS. Cryosections $(7 \mu \mathrm{m})$ were rehydrated in phosphate buffer $(\mathrm{PB})$ and blocked for $1 \mathrm{~h}$ using $10 \%$ goat or donkey serum, $0.4 \%$ Triton $\mathrm{X}-100$, and $0.1 \%$ BSA in PB. Primary antibodies were diluted in $0.3 \%$ goat or donkey serum, $0.4 \%$ Triton $\mathrm{X}-100$, and $0.1 \% \mathrm{BSA}$ in $\mathrm{PB}$ and incubated for $16 \mathrm{~h}$ at room temperature. Synthesis of Crb1, protein associated with Lin 
seven-1 (Pals1), and Mpp4 (membrane protein, palmitoylated 4) polyclonal rabbit antibodies have been described previously (van de Pavert et al., 2004; Kantardzhieva et al., 2005). Polyclonal anti-Crb2 was obtained from Dr. Rashbass (University of Sheffield, Sheffield, UK), and antiPals1-associated tight junction protein (Patj) was obtained from Dr. Le Bivic (Institut de Biologie du Développement de Marseille, Marseille, France). Anti-Mupp1 (multiple PDZ domain protein 1 ), $\beta$-catenin, cadherin, glutamine synthetase, and p120-catenin were monoclonal mouse antibodies and obtained from BD Biosciences (Erbodegem, Belgium). Anti-ZO-1 was a polyclonal antibody obtained from Santa Cruz Biotechnology (Santa Cruz, CA). Two different rabbit polyclonal anti-Pttg1 were obtained from Zymed (via Sanbio, Uden, The Netherlands), and another was kindly provided by Dr. Kakar (University of Louisville, Louisville, KY). Monoclonal mouse anti-Pttg1 was obtained from Dr. McCabe (University of Birmingham, Birmingham, UK). Goat or donkey secondary antibodies conjugated to Alexa488 or cyanine 3 (Cy3) (Jackson ImmunoResearch, West Grove, PA) were diluted in $\mathrm{PB}$ with $0.1 \%$ goat or donkey serum and incubated for $1 \mathrm{~h}$ at RT. For paraffin sectioning, the eyes were dehydrated through an ethanol series and imbedded in paraffin. Sections were made of $4 \mu \mathrm{m}$, deparaffinized in xylol, and rehydrated through an ethanol series. Sections were boiled for $10 \mathrm{~min}$ in $0.01 \mathrm{M}$

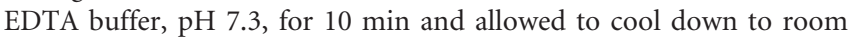
temperature, after which they were washed three times in PB. Blocking was done for $1 \mathrm{~h}$ in $10 \%$ goat serum and $0.1 \%$ BSA in PB. Primary antibodies were diluted in $0.3 \%$ goat serum and $0.1 \%$ BSA in PB and incubated for $16 \mathrm{~h}$ at room temperature. Goat secondary antibodies were diluted in PB with $0.1 \%$ goat or donkey serum and incubated for $1 \mathrm{~h}$ at RT. Sections were imaged on a Zeiss (Oberkochen, Germany) 501 confocal laser scanning microscope. Confocal images were processed with the Zeiss LSM image browser version 3.2, and figures were assembled in Adobe Photoshop version 7.0 (Adobe Systems, San Jose, CA).

Microarray. Retinas from 12-month-old, 3-d-light-exposed (3000 lux), female $\mathrm{Crbl}^{\mathrm{C} 249 \mathrm{~W} /-}$ mice and $\mathrm{Crb1}^{\mathrm{C249C/-}}$ (control) mice were homogenized, and total RNA was isolated by a single-step method, based on guanidine thiocyanate extraction, following the instructions of the manufacturer (Trizol; Invitrogen, Breda, The Netherlands). RNA integrity was assessed by gel electrophoresis with the $A_{260} / A_{280}$ absorbance ratios and the calculated RNA integrity number (Bioanalyzer; Agilent, Amstelveen, The Netherlands). Amplified RNA (aRNA) incorporated with Cy3 and Cy5 label (PerkinElmer, Groningen, The Netherlands) was generated with the Agilent low-input linear fluorescence amplification kit (Agilent). For the microarray, samples were used with comparable amounts of incorporated label, as assessed with the NanoDrop (Wilmington, DE) spectrophotometer. Oligonucleotide arrays were obtained from Agilent ( $22 \mathrm{~K}$ catalog mouse array 60 -mer; G4121). Five arrays were hybridized, each with $1.5 \mu \mathrm{g}$ of aRNA from an individual $\mathrm{Crb1}^{\mathrm{C} 249 \mathrm{~W} /-}$ mutant retina together with $1.5 \mu \mathrm{g}$ from an individual $\mathrm{Crbl}^{\mathrm{C} 249 \mathrm{C} /-}$ control retina using the protocol of Agilent. A dye swap was performed with five additional arrays to exclude differential dye effects. After washing and scanning (Agilent), the 10 arrays were normalized with Feature Extraction software (Agilent). Rosetta Resolver version 5 (Rosetta Biosoftware, Seattle, WA) was used for the analysis of the microarray data and to obtain the significant changed sequences.

Real-time quantitative PCR. Retinas were isolated for RNA isolation at the end of light exposure ( $3 \mathrm{~d}, 3000 \mathrm{lux})$ or 3-4 $\mathrm{h}$ after a dark period in light/dark cycle ( $12 \mathrm{~h}$ at 100 lux, $12 \mathrm{~h}$ at 0 lux) exposed female mice. The use of real-time quantitative PCR (qPCR) was described previously (Dijk et al., 2004). Briefly, qPCR primer pairs (supplemental Table 1, available at www.jneurosci.org as supplemental material) were designed using PrimerExpress version 2.0 software (PE Applied Biosystems, Warrington, UK). The length of the amplicons was kept as close as possible to $80-110 \mathrm{bp}$, and the melting temperature of the primers was set at 59$60^{\circ} \mathrm{C}$. Specificity of the primers was confirmed by BLAST searching. Total RNA, $1 \mu \mathrm{g}$, was reverse transcribed into first-strand cDNA with 100 U/ $\mu$ l Superscript III Plus RNase H-Reverse Transcriptase (Invitrogen) and $50 \mathrm{ng}$ random hexamer primers, during $50 \mathrm{~min}$ at $50^{\circ} \mathrm{C}$. To the resulting cDNA sample, $15 \mu \mathrm{l}$ of $10 \mathrm{~mm}$ Tris, $1 \mathrm{~mm}$ EDTA was added, bringing the volume to a total of $35 \mu \mathrm{l}$. From all samples, a 1:20 dilution was made and used for qPCR analysis. All samples were stored at $-20^{\circ} \mathrm{C}$ until analysis. To check the cDNA for any genomic contamination, a conventional end-point PCR for $\beta$-actin was performed using intronspanning primers with annealing at $60^{\circ} \mathrm{C}$, elongation at $74^{\circ} \mathrm{C}$, denaturing at $94^{\circ} \mathrm{C}, 90 \mathrm{~s}$ each step for 30 cycles, and $\mathrm{Mg}^{2+}$ concentration at $1.5 \mathrm{~mm}$ and $0.75 \mathrm{U}$ of TaqDNA Polymerase (Qiagen, Westburg, The Netherlands).

Real-time qPCR was based on the real-time monitoring of SYBR Green I dye fluorescence on a ABI Prism 7300 Sequence Detection System (Applied Biosystems, Nieuwekerk a/d IJssel, The Netherlands). The number of PCR cycles needed to pass a set threshold of SYBR Green fluorescence (cycle threshold) reflects, therefore, the template concentration in the original cDNA sample.

The PCR conditions were as following: $1 \times$ SYBR Green PCR buffer (Applied Biosystems), 3 mM MgCl $2,200 \mu \mathrm{M}$ dATP, dGTP, dCTP, $400 \mu \mathrm{M}$ dUTP, $0.5 \mathrm{U}$ of AmpliTaq Gold, $0.2 \mathrm{U}$ of AmpErase UNG (uracil- $N$ glucosylase), 2 pmol of primers, and $2 \mu$ of the 1:20 dilution of the cDNA in a total volume of $20 \mu \mathrm{l}$. This amount of cDNA corresponds to $\sim 2-4 \mathrm{ng}$ of total RNA. To determine the most stable reference genes, Genorm, a collection of VBA macros for Microsoft (Seattle, WA) Excel, was used (Vandesompele et al., 2002).

An initial step of $50^{\circ} \mathrm{C}$ for $2 \mathrm{~min}$ was used for AmpErase incubation followed by $10 \mathrm{~min}$ at $95^{\circ} \mathrm{C}$ to inactivate AmpErase and to activate the AmpliTaq. Cycling conditions were as follows: melting step at $95^{\circ} \mathrm{C}$ for $15 \mathrm{~s}$ and annealing/elongation at $60^{\circ} \mathrm{C}$ for $1 \mathrm{~min}$, with 40 cycles. At the end of the PCR run, a dissociation curve was determined by ramping the temperature of the sample from 60 to $95^{\circ} \mathrm{C}$ while continuously collecting fluorescence data. The curves of the melting profiles showed a single product and did not reveal accumulation of primer dimers as was confirmed by electrophoresis (data not shown). Nontemplate controls were included for each primer pair to check for any significant levels of contaminants.

Western blotting. Samples were boiled in sample buffer with $\beta$-mercaptoethanol, and the immunocomplexes were resolved by SDSPAGE. Subsequently, proteins were electrophoretically transferred onto nitrocellulose membranes, which were then blocked, incubated with primary and secondary antibodies (conjugated to horseradish peroxidase) in $0.3 \%$ milk powder/TBST (50 mм Tris, $\mathrm{pH} 7.5,150 \mathrm{~mm} \mathrm{NaCl}$, and $0.05 \%$ Tween-20), and washed in TBST. The bands were visualized using supersignal west pico chemiluminescent substrate (Pierce, via Perbio Science Nederland, Etten-Leur, The Netherlands).

Electroretinography and scanning laser ophthalmoscopy. ERGs and scanning laser ophthalmoscopies (SLOs) were obtained according to previously reported procedures (Seeliger et al., 2001, 2005). Briefly, after dark adaptation overnight, mice were anesthetized with ketamine (66.7 $\mathrm{mg} / \mathrm{kg}$ ) and xylazine $(11.7 \mathrm{mg} / \mathrm{kg})$, and the pupils were dilated. The ERG equipment consisted of a Ganzfeld bowl, a direct current amplifier, and a personal computer-based control and recording unit (Multiliner Vision; Jaeger-Toennies, Hoechberg, Germany). Band-pass filter cutoff frequencies were 0.1 and $3000 \mathrm{~Hz}$. Single-flash recordings were obtained both under dark-adapted (scotopic) and subsequently light-adapted (photopic) conditions. Light adaptation was achieved with a background illumination of $30 \mathrm{~cd} / \mathrm{m}^{2}$ starting $10 \mathrm{~min}$ before photopic recordings. Single-flash stimulus intensities were increased from $10^{-4}$ to $25 \mathrm{~cd}^{\star} \mathrm{s} / \mathrm{m}^{2}$, divided into 10 steps of 0.5 and $1 \log \mathrm{cd}^{\star} \mathrm{s} / \mathrm{m}^{2}$. Ten responses were averaged with an interstimulus interval of either 5 or $17 \mathrm{~s}$ (for 1, 3, 10, and 25 $\left.\mathrm{cd}^{*} \mathrm{~s} / \mathrm{m}^{2}\right)$.

Fundus imaging was performed with an HRA SLO (Heidelberg Instruments, Heidelberg, Germany) that provides two argon wavelengths (blue, $488 \mathrm{~nm}$; and green, $514.5 \mathrm{~nm}$ ) and an infrared diode laser (690 nm) for fundus visualization. The confocal diaphragm of the SLO allows imaging of different planes of the posterior pole, ranging from the surface of the retina down to the retinal pigment epithelium and the choroid. Different planes can be viewed by varying the focus by approximately \pm 20 diopters.

\section{Results \\ Generation of $\mathrm{Crb1}{ }^{\mathrm{C249W/-}}$ mice}

To generate a mouse model for RP12, we designed a targeting construct that introduced a single base pair mutation in exon 3 of Crb1 (Fig. 1A). Homologous recombination events were scored 

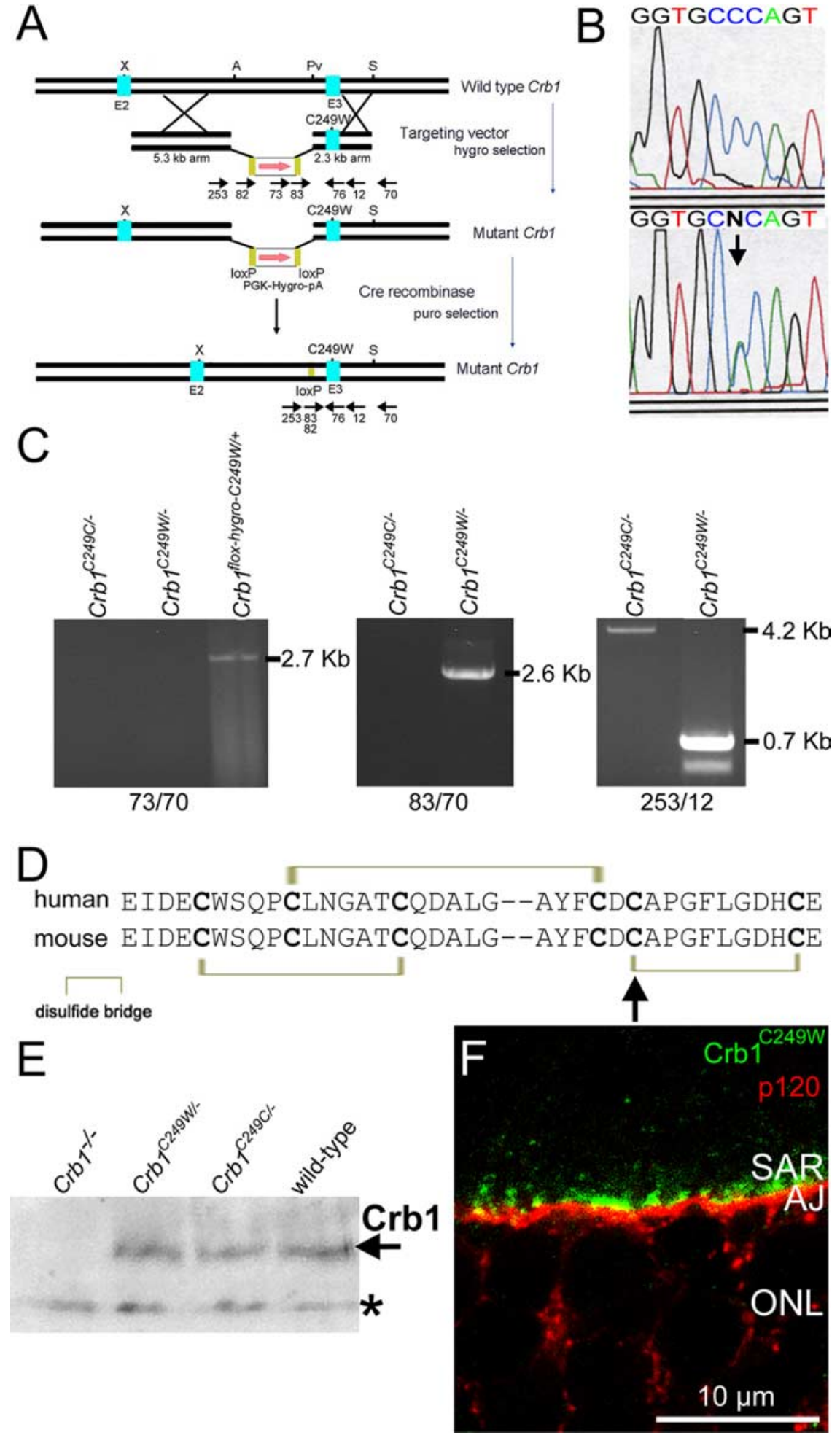

Figure 1. Generation of $\mathrm{Crb}^{\mathrm{C}(249 \mathrm{~W} /-}$ mice. A, Strategy for homologous recombination in mouse embryonic stem cells. A wild-type Crb7 exon 3 is replaced by a mutant exon 3 harboring a TGT to TGG point mutation in codon 249. Arrows indicate the primer number and location. A, Apal; E2, exon 2; E3, exon 3; Pv, Pvull; S, Spel; X, Xhol. B, Top, Electropherogram and reverse sequence (CCA) of the mutant mouse allele specifically amplified with primers JW83 (loxP) and JW12 (intron 3). Bottom, Electropherogram and sequence of the wild-type $(\underline{A} C A)$ and mutant $(C C A)$ mouse alleles $(N C A)$ amplified with primers JW74 (exon 3) and JW12 (intron 3). C, Long-distance PCR analysis on Crb $1^{\text {flox-hygro-C249W/+ }}$ ES cell DNA, control Crb $7^{(249) /-}$, and mutant $\mathrm{Crb}^{\mathrm{C} 249 \mathrm{~W} /-}$ mouse tail DNA with the used primer pairs stated below the figures. D. The substituted cysteine in the sixth EGF domain in RP12 patients and $\mathrm{Crb}^{\mathrm{C}}{ }^{\mathrm{C} 49 \mathrm{~W}}$ mutant mice is indicated by the arrow. Disulphide bridges between the cysteines are

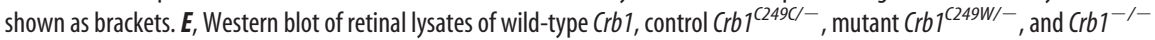
mice incubated with anti-Crb1 (AK2). The asterisk indicates a cross-hybridizing band. $\boldsymbol{F}$, High-magnification confocal image of the OLM of three-month-old $\mathrm{Crb}^{\mathrm{C} 249 \mathrm{~W} /-}$ retina, showing $\mathrm{Crb}^{\mathrm{C} 249 \mathrm{~W}}$ at the SAR (green) and p120 - catenin at the adherens junction region (red). AJ, Adherens junction. by analysis of sequencing electropherograms and long-distance PCR (Fig. $1 B, C$ ). The mutation substituted at position 249 a codon (TGT) for cysteine (C) into a codon (TGG) for tryptophan (W). Mouse Crb1 contains 17 intact and two degenerate putative EGF domains (den Hollander et al., 2002). The amino acid substitution C249W in the sixth EGF domain disrupts the disulfide bridging between cysteines 249 and 258 (Fig. 1D). Heterozygous Crb1 $1^{\text {C249W/C249C }}$ mice were crossed with $\mathrm{Crb1}^{-/-}$knock-out mice. Crb1 ${ }^{\mathrm{C} 249 \mathrm{~W} /-}$ mutant mice were viable, healthy, and fertile, with no apparent phenotype during 2 years after birth. Wild-type Crb1 and mutant Crb1 ${ }^{\mathrm{C} 249 \mathrm{~W}}$ proteins of comparable molecular weight were produced at similar levels in $\mathrm{Crbl}^{\mathrm{C} 249 \mathrm{Cl}-}$ control and $\mathrm{Crb1}^{\mathrm{C} 249 \mathrm{~W} / \mathrm{-}}$ mutant mice, respectively (Fig. $1 E$ ). The Crb $1{ }^{\mathrm{C} 249 \mathrm{~W}}$ protein localized at a subapical region adjacent to adherens junctions at the outer limiting membrane (OLM) of the retina, similar to the wildtype protein (Figs. 1F, 2). These results suggest that mouse $\mathrm{Crb} 1^{\mathrm{C} 249 \mathrm{~W}}$ in Crb1 ${ }^{\mathrm{C} 249 \mathrm{~W} /-}$ mutant mice and human CRB1 ${ }^{\mathrm{C} 250 \mathrm{~W}}$ in RP12 patients are correctly trafficked to and positioned in the plasma membrane.

\section{Retinal folds and loss of photoreceptors} in $\mathrm{Crb1}^{\mathrm{C} 249 \mathrm{~W} /-}$ mice

To check for retinal degeneration and changes in the Crb1 protein complex, retinal sections were examined by histochemistry and immunohistochemistry. Previously, in $\mathrm{Crb1}^{-/-}$mice, we observed focal retinal disorganization and degeneration within 3-6 months of age attributable to loss of the capacity to maintain adhesion between photoreceptors and Müller glia cells (van de Pavert et al., 2004). In $\mathrm{Crb1}^{\mathrm{C} 249 \mathrm{~W} / \mathrm{-}}$ mice, no retinal abnormalities were observed until 8 months of age. The $\mathrm{Crb1}^{\mathrm{C} 249 \mathrm{~W}}$ allele in $\mathrm{Crb1} 1^{\mathrm{C} 249 \mathrm{~W} /-}$ mice delayed the onset of retinal phenotype as observed in $\mathrm{Crbl}^{-/-}$mice. These results suggest that the mutant $\mathrm{Crb} 1^{\mathrm{C} 249 \mathrm{~W}}$ protein, which causes RP12 in humans, is involved in maintaining adhesion between photoreceptors and Müller glia cells. A mild focal phenotype, consisting of photoreceptor layer folds without signs of retinal degeneration, became detectable at 8-12 months of age (Fig. 2A, $B$; Table 2). Darkstained condensed nuclei were detected in the apical part of the inner nuclear layer (INL) at areas in which the outer nuclear layer (ONL) was folded. These structures might represent nuclei of stretched Müller glial cells (MGCs) (Figs. 2B, 3, arrows). Although observed in all $\mathrm{Crb}^{-/-}$retinas, 
in only 1 retina of 28 tested was an ingression of photoreceptor nuclei into the outer plexiform layer observed (Fig. 2C). No condensed and dark-stained INL nuclei were observed immediately below this ingression. In 2 of $17 \mathrm{Crbl}^{\mathrm{C} 249 \mathrm{C} /-}$ control retinas, retinal folds encompassing all layers of the retina were observed at the nervus opticus. The folds around the nervous opticus might be attributable to handling of the eye during enucleation before fixation of the tissue and were excluded. At 18 and 24 months of age, areas of the ONL were significantly thinner compared with the control (Fig. 2D-F). Apoptosis was undetectable by terminal deoxynucleotidyl transferase-mediated dUTP nick end labeling assay (data not shown), suggesting a gradual decline in number of photoreceptor cells.

Proteins associated with the Crbscaffold at the OLM, such as Crb1, Crb2, Pals1 (Mpp5), Patj, or Mupp1, were not mislocalized, not even in folds (Fig. $2 G$ and data not shown). Neither were proteins that are associated with the adherens junction such as ZO-1, $\beta$-catenin, cadherin, and p120-catenin (Fig. $2 G$ and data not shown). CD44, a marker for the apical villi in MGC, is also localized normally (Fig. $2 H, I)$. The localization of MGC marker glial fibrillary acidic protein (GFAP) is normally restricted to the inner plexiform layer and ganglion cell layers (Fig. $2 H$ ), but, in affected areas in the Crb1 $1^{\mathrm{C} 249 \mathrm{~W} /-}$ retina, staining for GFAP extends at foci into the ONL (Fig. $2 \mathrm{H}, \mathrm{I}$ ).

Mild light exposure increases the incidence of $\mathrm{Crb1}{ }^{\mathrm{C249W/-}}$ retinas with ONL folds

$\mathrm{Crb1}^{-/-}$retinas developed significantly more lesions after mild light exposure at 3 months of age (van de Pavert et al., 2004). $\mathrm{Crb1}^{\mathrm{C} 249 \mathrm{~W} /-}$ animals of $3,8,12$, and 14 months of age were exposed to mild light conditions, i.e., 3000 lux for 72 h. At 3 months, folds of the photoreceptor layer were not observed in mild-light-exposed $\mathrm{Crb}^{\mathrm{C} 249 \mathrm{C} /-}$ control or $\mathrm{Crb} 1^{\mathrm{C} 249 \mathrm{~W} /-} \mathrm{mu}-$ tant retinas. These experiments support the notion that one mutant $C r b 1^{C 249 W}$ allele is sufficient to prevent retinal disorganization at 3 months. Mild light exposure to 8 - and 12-month-old mice significantly increased the incidence of retinas with one to three folds in the ONL (Table 2; Fig. $3 A, B$ ). However, the total number of folds per retina (one to three) did not increase. In none of the $C r b 1^{C 249 C /-}$ control retinas were folds observed. Staining for GFAP extends at foci into the ONL (Fig. 3C,D). These experiments suggest that the C249W substitution affects the function of Crb1 in protection against light effects.
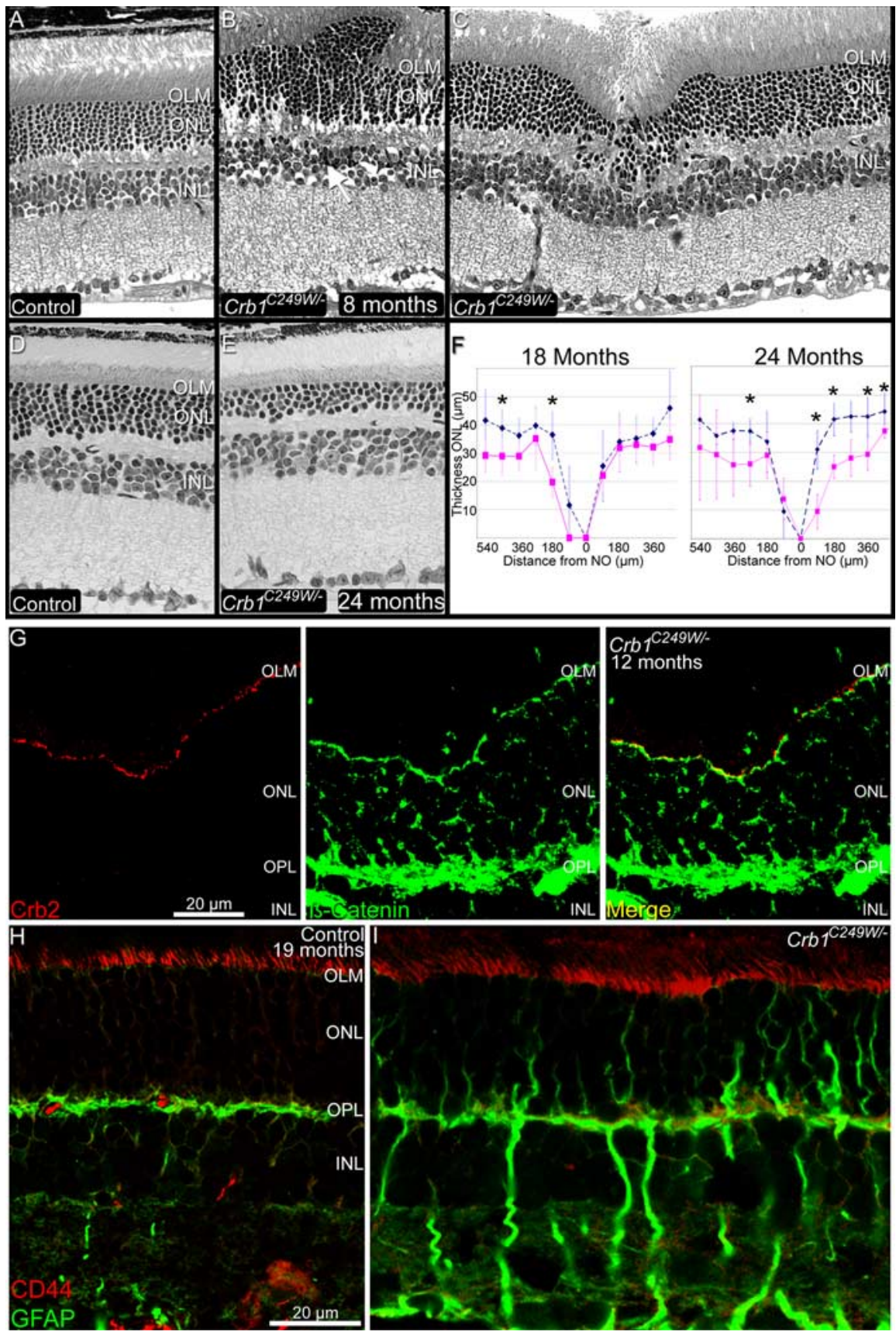

Figure 2. $\quad \mathrm{Crb1} 1^{\mathrm{C} 249 \mathrm{~W} /-}$ histology. A, $\mathrm{Crb} 1^{\mathrm{C249C} /-}$ control retina at 8 months of age. B, A typical fold of the ONL of an 8-monthold $\mathrm{Crb}^{\mathrm{C} 249 \mathrm{~W} /-}$ mutant retina. The arrow indicates dark condensed nuclei in the INL. C, A rare ingression of photoreceptors into the OPL layer detected in a $C r b 1^{\mathrm{C} 249 W /-}$ retina. D, Control retina at 24 months of age. $\boldsymbol{E}$, In the $\left(\mathrm{rb} 1^{\mathrm{C} 249 W /-}\right.$ retina, the ONL is significantly thinner at older age. $\boldsymbol{F}$, The measured thickness of the $0 \mathrm{NL}$ in 18 -month-old (control, $n=5 ;\left(\mathrm{rbr}^{\mathrm{C} 249 \mathrm{~W} /-}, n=5\right)$ and 24-month-old (control, $\left.n=4 ; \mathrm{Crb}^{\mathrm{C249W/-}}, n=5\right) \mathrm{Crb1}^{\mathrm{C} 249 \mathrm{~W} /-}$ retinas (red) versus control (blue). N0, Nervus opticus. Error bars represent the SEM. Significant changes calculated by Student's $t$ test are depicted by asterisks $(p<0.05) . \mathbf{G}$, In and around folds, the OLM appears normal, as visualized with the subapical region marker $\mathrm{Crb2}$ and the adherence junction marker $\beta$-catenin in a 12-month-old Crb1 ${ }^{\mathrm{C} 249 \mathrm{~W} /-}$ retina. $\boldsymbol{H}$, In MGCS, CD44 is located in the apical villi and GFAP located in the OPL but not in the ONL of a 19-month-old control retina. I, Although GFAP is located in the ONL, CD44 is located normally in the apical villi of the MGC.

\section{Electroretinography and scanning laser ophthalmoscopy}

In all examined $\mathrm{Crb} 1^{\mathrm{C249C/-}}$ control and $\mathrm{Crb1} 1^{\mathrm{C} 249 \mathrm{~W} /-}$ mutant retinas of $3,8,12,18$, or 30 months-of-age with or without light exposure, no differences in electroretinograms were observed (data not shown). Aged mice showed large variations in ERG, and therefore differences could not be detected between mutant and control mice. Retinas of 30-month-old Crb1 ${ }^{\mathrm{C} 249 \mathrm{C} /-}$ control 
Table 2. Number of retinal folds

\begin{tabular}{|c|c|c|c|c|c|}
\hline \multirow[b]{2}{*}{$\begin{array}{l}\text { Months of } \\
\text { age }\end{array}$} & \multicolumn{3}{|c|}{$\mathrm{Crb1}^{\mathrm{C} 249 \mathrm{~W} /-}$ mutant } & \multicolumn{2}{|c|}{$\mathrm{Crb1}^{\mathrm{C249C/}-}$ control } \\
\hline & $\begin{array}{l}\text { Mice with } \\
\text { retinal folds }\end{array}$ & $\begin{array}{l}\text { Mice without } \\
\text { retinal folds }\end{array}$ & $\%$ folds & $\begin{array}{l}\text { Mice with } \\
\text { retinal folds }\end{array}$ & $\begin{array}{l}\text { Mice without } \\
\text { retinal folds }\end{array}$ \\
\hline $3+L$ & 0 & 5 & 0 & 0 & 3 \\
\hline 8 & 2 & 4 & 33 & 0 & 3 \\
\hline $8+L$ & 4 & 5 & $44^{*}$ & 0 & 3 \\
\hline 12 & 0 & 6 & 0 & 0 & 4 \\
\hline $12+L$ & 4 & 3 & $57^{*}$ & 0 & 5 \\
\hline 18 & 0 & 5 & 0 & 0 & 5 \\
\hline 24 & 0 & 5 & 0 & 0 & 4 \\
\hline
\end{tabular}

The number of retinas in $\mathrm{Crb}^{\mathrm{C} 249 \mathrm{C} /-}$ control or $\mathrm{Crb}^{\mathrm{C} 249 \mathrm{~W} /-}$ animals with one to three or without retinal folds. The retina of the right eye of each animal was checked. Depicted in the first column are the ages of the animals in months, without or with mild light exposure $(+\mathrm{L})$. In the light-exposed ( $3 \mathrm{~d}$ at 3000 lux versus normal dark/light-cycle-exposed 8 - and 12-month-old retina, there was a statistically significant difference ( ${ }^{*} p=0.02$, one-sided $\chi^{2}$ test).
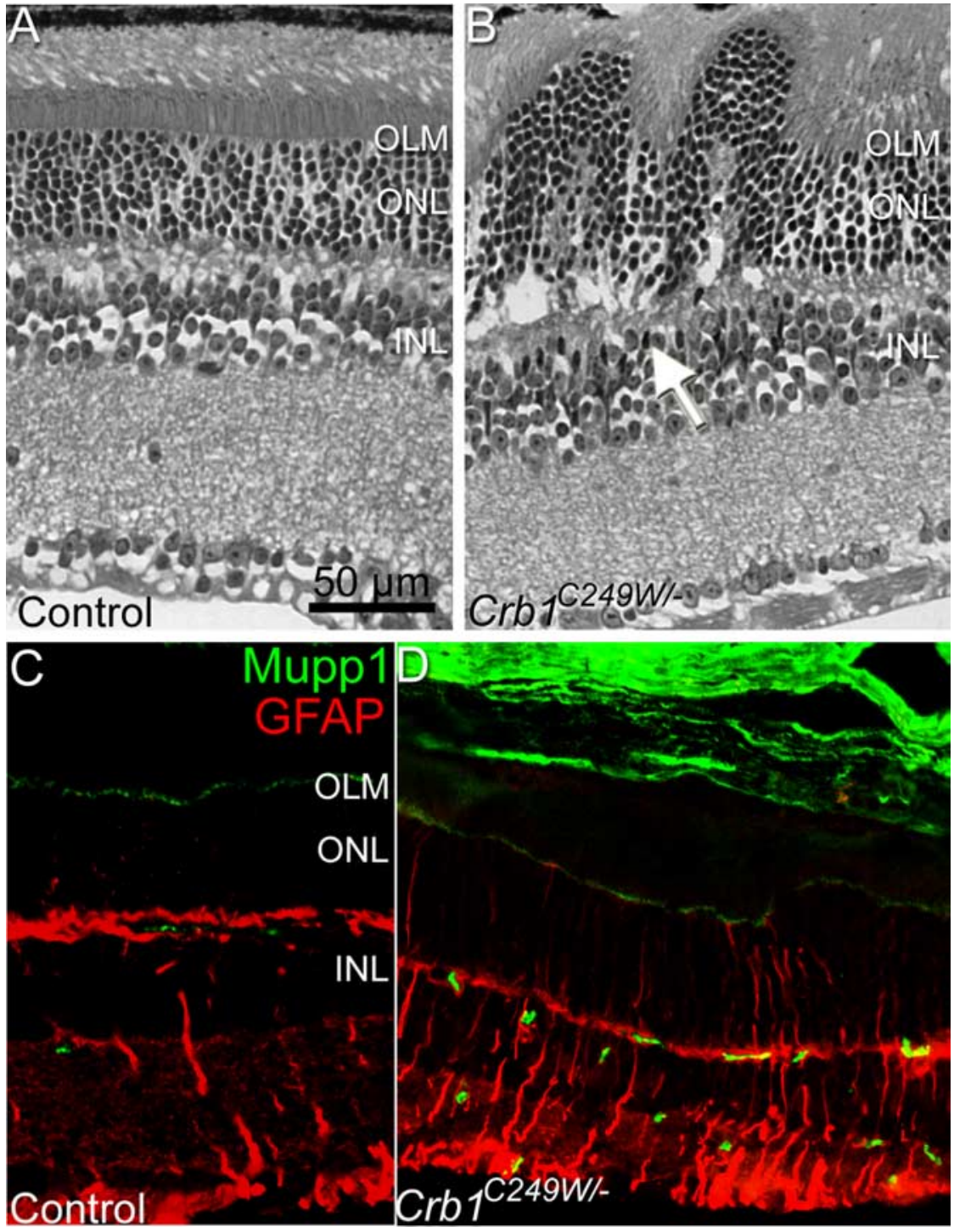

Figure 3. Mild light exposure affects the phenotype of the $\mathrm{Crb1} 7^{\mathrm{C} 249 \mathrm{~W} /-}$ retina. $\boldsymbol{A}$, Light exposure did not have any effect on the control retinas, but occasionally two folds appeared in the $\mathrm{Crb}_{1}{ }^{(249 \mathrm{~W} /-}$ retina $(\boldsymbol{B})$. In 12-month-old animals exposed for $72 \mathrm{~h}$ with 3000 lux, the subapical region marker, and part of the Crb1 scaffold, Mupp1 is localized normally in control (C) as in a $\mathrm{Crb} 1^{\mathrm{C} 249 \mathrm{~W} /-}$ (D) retina. However, GFAP was more intense and located in the MGC fibers in the ONL in the $\mathrm{Crb}_{1}^{\mathrm{C} 249 \mathrm{~W} /-}$, indicating retinal stress at foci. Scale bar, $50 \mu \mathrm{m}$.

and $\mathrm{Crb}^{\mathrm{C} 249 \mathrm{~W} /-}$ mutant mice were examined by scanning laser ophthalmoscopy but, because of cataract, gave no interpretable results. However, in retinas from 18-month-old animals, autofluorescent dots (Fig. 4, arrows) were observed in five of the six studied $\mathrm{Crb} 1^{\mathrm{C} 249 \mathrm{~W} /-}$ mutant retinas, whereas in all four $\mathrm{Crbl}^{\mathrm{C249C/} /}$ control animals, these spots were absent. Furthermore, a leopard skin appearance was detected in $514 \mathrm{~nm}$ fundus images of almost all $\mathrm{Crb} 1^{\mathrm{C} 249 \mathrm{~W} /-}$ retinas, which is typical for crosses between unequally pigmented mouse lines. Because this appearance was found as well in $\mathrm{Crbl}^{\mathrm{C249C/-}}$ control retinas (Fig. 4), the genetic background is not a probable cause for the autofluorescence changes observed. Histological analysis of these eyes did not reveal any other reason for the leopard skin appearance. However, the autofluorescent dots are usually indicative of folds, rosettes, or lipid deposits in the retina (Seeliger et al., 2005).

\section{Downstream signaling of Crb1}

Expression profiling of mutant compared with control retinas was performed by oligonucleotide microarray analysis using the $22 \mathrm{~K}$ catalog array from Agilent. In this comparison, retinas from five lightexposed $(72 \mathrm{~h}$ at 3000 lux $)$ mutant $\mathrm{Crbl}^{\mathrm{C249W/-}}$ and control $\mathrm{Crbl}^{\mathrm{C249C/-}}$ eyes from 12-month-old mice were compared on five arrays. Also, a dye swap of the aRNA was included to eliminate dye bias. In total, 10 arrays were analyzed. Scanned images were analyzed with Feature Extraction version 7 . This program calculated the intensity of the signal in ratios of the $\mathrm{Cy} 3$ versus the Cy5 channel. Using Rosetta Biosoftware, a comparison and average for ratios and errors of every spot was made for all arrays. In Table 3, a list of genes is presented that were changed at least 1.5 times with a $p$ value of $<0.001$ (Student's $t$ test).

Confirmation of this set of genes by qPCR resulted in the validation of three genes, i.e., connective tissue growth factor (Ctgf), endothelin 2 (Edn2), and Pttg1. Levels of Pttg1, encoding a transcription regulatory protein that can shuttle between cytoplasm and nucleus (Heaney et al., 1999), were substantially lower (37fold; $n=5$ mutant, $n=5$ control retinas; $p<1 \times 10^{-6}$ ) in the $\mathrm{Crbl}^{\mathrm{C} 249 \mathrm{~W} /-}$ retina. We hypothesized that the $C r b 1^{C 249 W}$ to Pttg1 gene signaling function would also be lost in $\mathrm{Crb1}^{-1-}$ knock-out mice. In 3-month-old $\mathrm{Crb1}^{-1-}$ retinas exposed for $72 \mathrm{~h}$ to 3000 lux, we detected lower Pttg1 RNA levels (17-fold; $n=13$ mutant, $n=$ 13 wild-type retinas; $p<0.0005$ ) (Fig. 5). However, in normal housed dark/lightcycled ( $12 \mathrm{~h}$ at 100 lux followed by $12 \mathrm{~h}$ at 0 lux) mice, levels of Pttg1 were not different $(n=12$ mutant and $n=14$ wild-type retinas; $p>0.05$ ) between the wild-type and $\mathrm{Crbl}^{-1-}$ knock-out retinas. There was also no difference between the levels of Pttg 1 in wild-type retina continuously exposed for $72 \mathrm{~h}$ to $3000 \operatorname{lux}(n=$ 
5) versus wild-type retinas exposed to dark/light cycle $(n=14)(p>0.05)$. To test whether the decrease in retinal Pttg1 RNA is Crb1 mutant specific, we tested Pttg1 RNA levels in other mutant retinas. $M p p 4^{-/-}$knock-out photoreceptors show loss of Mpp4, retinal folds, and concomitant mislocalization of Mpp4-interacting proteins at the photoreceptor synapse (Aartsen et al., 2006). Pttg1 levels were not changed in 3-month-old Mpp4 $4^{-1-}$ knockout retinas exposed for $72 \mathrm{~h}$ to $3000 \mathrm{lux}$ ( $n=5$ mutant, $n=5$ wild-type; relative expression levels of $0.33 \pm 0.21$ in wildtype and $0.67 \pm 0.26$ in $M p p 4^{-/-}$knockout; $p>0.05)$.

Whereas Pttg1 transcript levels were relatively high in wild-type and low in Crb1 light-exposed mutant retinas, Pttg1 protein could not be detected in wild-type or mutant retinas. We used four different antibodies against Pttg1 (two batches of Zymed, one from Dr. Kakar and one from Dr. McCabe), that cross-hybridized with different retinal proteins. One of the antibodies (from Dr. McCabe) showed a mouse pituitary-gland-specific $26 \mathrm{kDa}$ band, but none of the antibodies showed retina-specific $28 \mathrm{kDa}$ Pttg1 bands on Western blots (data not shown), suggesting low Pttg1 protein levels in retina. We used the same four antibodies in immunohistochemistry to determine the protein localization of Pttg1 in retina, but these experiments gave non-interpretable results (data not shown).

\section{Discussion}

Different mutations in the human $C R B 1$ gene cause a variety of retinal dystrophies, such as LCA, RP12, and other types of early onset RP, e.g., RP with Coats-like exudative vasculopathy and pigmented paravenous retinochoroidal atrophy. Previously, we generated $\mathrm{Crb1}^{-/-}$mice as a putative mouse model for LCA (van de Pavert et al., 2004). Here, we generated $C r b 1^{C 249 W /-}$ mice as a putative mouse model for RP12 and show deregulation of Pttg1 expression attributable to a $\mathrm{C} 249 \mathrm{~W}$ substitution in the extracellular domain of Crb1.

\section{Crb1 $1^{\mathrm{C} 249 \mathrm{~W} /-}$ mice as a mouse model for RP12}

In humans, a C250W amino acid substitution in the CRB1 protein results in the eye disease RP12. RP12 is characterized by early onset RP with preserved para-arteriolar retinal pigment epithelium. Significant loss of vision as measured by ERG is observed in these patients within the first two decades of their life. However, histological data describing early or late stages of retinal degeneration in RP12 patients are not available. We propose that amino acid C249 in the extracellular domain of Crb1 is the equivalent of C250 in CRB1, because both are involved in similar disulfide bridging. Wild-type full-length mouse Crb1 is localized in Müller glia cells at an SAR adjacent to adherens junctions at the outer limiting membrane (van Rossum et al., 2006). The Crb1 ${ }^{\mathrm{C} 249 \mathrm{~W}}$ protein trafficked as the wild-type protein to the SAR. This suggests that, in RP12 patients, CRB $1{ }^{\mathrm{C} 250 \mathrm{~W}}$ resides correctly at the SAR and has partial activity. The introduction of a $\mathrm{Crb1} 1^{\mathrm{C} 249 \mathrm{~W}}$ allele in $\mathrm{Crb1}^{-/-}$mice results in significant rescue of the retinal phenotype in $\mathrm{Crb1}^{-/-}$mice. The $\mathrm{Crb1}^{\mathrm{C} 249 \mathrm{~W} /-}$ mice showed folds of the photoreceptor layer, but, as was observed in other retinal degeneration models (Akhmedov et al., 2000), these folds were transient. Moreover, these transient folds did not coincide with the onset of retinal degeneration but might indicate increased plasticity of the mutant photoreceptor layer. Only at 18 months of age and onward did the $\mathrm{Crb1} 1^{\mathrm{C} 249 \mathrm{~W} /-}$ retinas show significant degeneration. Histological analysis of the mutant mice at 18 and 24 months of age showed significant loss of photoreceptors in regions of the retina. This degeneration did not affect other neural layers in the retina, being different from $\mathrm{Crb}^{-/-}$retinas that showed degeneration at foci of all, except the ganglion, neural layers.

Loss of retinal electrical activity could not be detected by ERG at 18 or 30 months of age. The relatively late onset of retinal degeneration may be attributable to the genetic background of the mice or to redundancy of Crb proteins. Mehalow et al. (2003) showed that the C57BL/6 genetic background could fully suppress the retinal phenotype observed in $C r b 1^{r d 8 / r d s}$ mice that harbor a frame shift in the Crb1 gene after codon 1160 . The previously analyzed $\mathrm{Crb1}^{-1-}$ mice were on the same genetic background as the $\mathrm{Crb}^{\mathrm{C249W/-}}$ mice, showing that different mutations in the $C r b 1$ gene result in different phenotypes.

Exposure to relatively low doses of white light accelerated significantly the retinal disorganization and degeneration in $\mathrm{Crb1}^{-1-}$ mice (van de Pavert et al., 2004). Experiments on fruit fly Crumbs showed that the extracellular domain played an important role in prevention against light damage (Johnson et al., 2002). Here, we show that the amino acid substitution in Crb1 ${ }^{\mathrm{C} 249 \mathrm{~W}}$ caused loss of protection against the effects of light (increased incidence of retinal folds and upregulation of GFAP at foci, and low levels of retinal Pttg1 transcripts).

$C r b 1^{r d 8 / r d s}$ mice showed reduced length of photoreceptor inner segments (Mehalow et al., 2003), correlating well with the previously observed reduction in length of the stalk membrane in Crumbs mutant fruit fly photoreceptors (Pellikka et al., 2002). However, similar to $\mathrm{Crb1}^{-/-}$mice (van de Pavert et al., 2004), 
Table 3. Differentially expressed genes in $\mathrm{Crb1}^{\mathrm{C249W} /}$ - retinas versus $\mathrm{Crb}^{\mathrm{C249C}-}$ control retinas

\begin{tabular}{|c|c|c|c|c|c|}
\hline Accession \# & Symbol & Gene name & Microarray (fold change) & qPCR (fold change) & $p$ value \\
\hline AK047380 & Fin15 & Fibroblast growth factor inducible 15 & +5.1 & +1.0 & * \\
\hline NM_008613 & Mns1 & Meiosis-specific nuclear structural protein 1 & +2.6 & -1.5 & * \\
\hline NM_173384.1 & Sox30 & SRY-box containing gene 30 & +2.5 & +1.4 & * \\
\hline NM_007902 & Edn2 & Endothelin 2 & +2.1 & +1.9 & 0.04 \\
\hline NM_008200 & $\mathrm{H} 2-\mathrm{D} 4$ & Histocompatibility 2, D region locus 4 & +1.8 & +1.6 & * \\
\hline NM_007913 & Egr1 & Early growth response 1 & +1.7 & +1.3 & * \\
\hline NM_011795 & C1qrf-pending & C1q related factor & +1.6 & +1.5 & * \\
\hline AK011787 & 2610100L16Rik & 2610100L16Rik & +1.5 & +1.1 & * \\
\hline ВС029968 & 5430407P10Rik & 5430407P10Rik & +1.5 & +1.2 & * \\
\hline NM_009872 & Cdk5r2 & Cyclin-dependent kinase 5, regulatory subunit 2 & +1.5 & +1.3 & * \\
\hline NM_007734 & Col4a3 & Procollagen-type IV alpha 3 & +1.5 & +1.1 & * \\
\hline NM_009252 & Serpina3n & Serine proteinase inhibitor, $A$, member $3 \mathrm{~N}$ & +1.5 & -1.2 & * \\
\hline AK006434 & 1700027L20Rik & 1700027L20Rik & +1.5 & +1.4 & 0.05 \\
\hline XM_140952 & Crb2 & Crumbs homologue 2 & ND & -1.0 & * \\
\hline NM_010217 & Ctgf & Connective tissue growth factor & -1.5 & -1.7 & 0.03 \\
\hline BC019757 & Hist1h4i & $\mathrm{H} 4$ histone family, member $\mathrm{A}$ & -1.5 & & \\
\hline NG_001394.1 & NG_001394.1 & HMG-box-1, related sequence 18 pseudogene & -1.6 & +1.1 & * \\
\hline U76426 & K-ras & K-ras type B & -1.6 & +1.3 & * \\
\hline AK045478 & C030033F14Rik & Protocadherin 17 & -1.6 & +1.2 & * \\
\hline AK082887 & C430003P19Rik & C430003P19Rik & -1.7 & +1.2 & * \\
\hline NM_022410 & Myh9 & Myosin heavy chain IX & -1.7 & +1.7 & * \\
\hline NM_024228 & 1110015E22Rik & 1110015E22Rik & -2.9 & -1.0 & * \\
\hline NM_021365 & XIr4 & X-linked lymphocyte-regulated 4 & -3.4 & +1.1 & * \\
\hline AK008704 & Pttg1 & Pituitary tumor transforming gene 1 & -6.2 & -37.0 & $<1 \times 10^{-6}$ \\
\hline
\end{tabular}

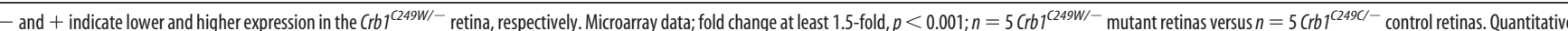
reverse transcription-PCR data; $p$ values calculated using the Student's $t$ test with one tail. $C r b 2 \mathrm{mRNA}$ was analyzed with quantitative reverse transcription-PCR, for a possible rescuing effect for family member Crb1, but was not significantly changed. ${ }^{*} p>0.05$.
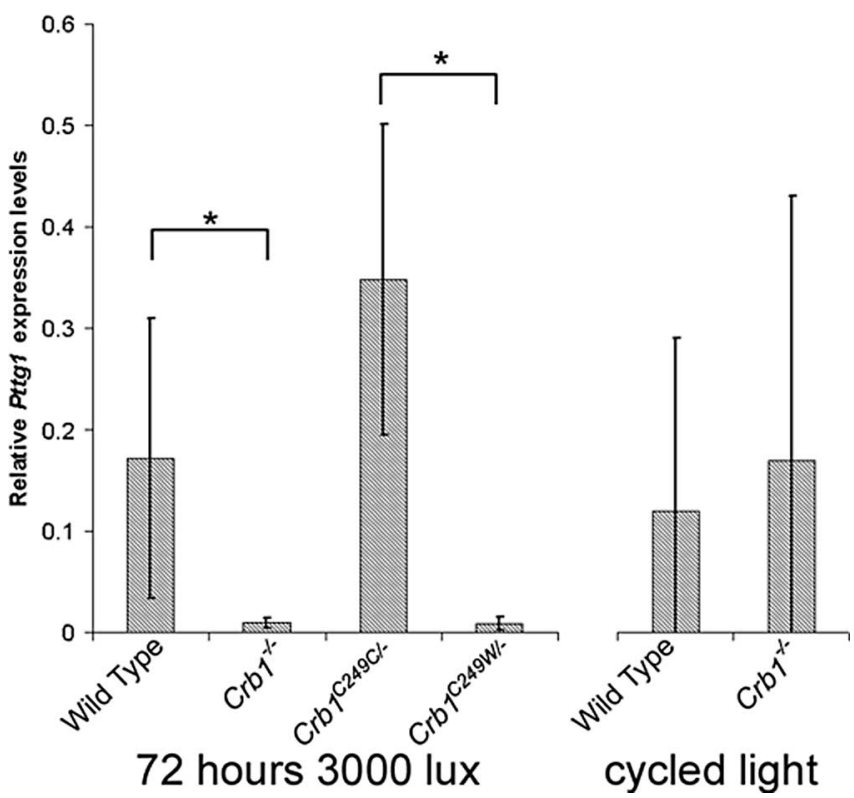

Figure 5. The relative expression levels of Pttg 1 in Crb1 mutant retinas. Wild-type $(n=13)$ and $\mathrm{Crb}^{-/-}$knock-out $(n=13)$ or $\mathrm{Crb}^{(249 \mathrm{Cl}-}$ control $(n=5)$ and $\mathrm{Crb}^{\mathrm{C} 249 \mathrm{~W} /-}$ mutant $(n=5)$ mice were light exposed ( $72 \mathrm{~h}$ at 3000 lux) or exposed to cycled light ( $12 \mathrm{~h}$ at 0 lux, $12 \mathrm{~h}$ at 100 lux; $n=14$ wild-type and $n=12\left(\mathrm{Cb}^{-/-}\right.$knock-out mice). Values are presented as mean \pm SD. ${ }^{*} p<0.0005$. Relative expression levels for $\mathrm{Crb} 1$ in animals exposed for $72 \mathrm{~h}$ to 3000 lux were $2.1 \pm 0.9$ in wild-type $(n=13)$ and $0.06 \pm 0.06 \mathrm{in} \mathrm{Crb} 1^{-/-}$knock-out $(n=$ 13) retinas.

Crb1 ${ }^{C 249 W /-}$ mice did not show reduced length of photoreceptor inner segments in unaffected regions.

Protein markers for the SAR and adherens junction showed no differences between mutant and control retinas, suggesting that no major changes occurred in protein complexes at the OLM. Mouse and human retina showed colocalization of Crb1,
Crb2, and Crb3 at a subapical region adjacent to adherens junctions at the outer limiting membrane (van de Pavert et al., 2004). Crb1 and Crb2 have similar extracellular domains that might function as signal receptors and/or interaction domains with the extracellular matrix. Crb1-Crb3 have highly conserved 37 amino acid $\mathrm{C}$ termini that are likely to bind the same intracellular protein complex that might exert similar functions (Roh et al., 2002; Meuleman et al., 2004). The unchanged endogenous levels of Crb2 and Crb3 proteins were not able to prevent late onset of retinal degeneration in $\mathrm{Crbl}^{\mathrm{C} 249 \mathrm{~W} /-}$ mice.

\section{The extracellular domain of Crb1 positively regulates Pttg1 transcript levels}

Pttg1 was downregulated 37-fold. Only two other genes were statistically significantly downregulated or upregulated as assessed by qPCR. Ctgf was downregulated 1.7-fold, and Edn2 was upregulated 1.9-fold. Changes of Ctgf and Edn2 expression in retinal degeneration has been observed previously (Tikellis et al., 2004; Rattner and Nathans, 2005).

Pttg1 was originally found in pituitary tumors and is also known as securin. Pttg1 is a mitotic checkpoint protein that inhibits sister chromatid separation during mitosis. Several other functions have been attributed to this cytoplasmic and nuclear protein, such as regulation of gene transcription, cell proliferation, and apoptosis (Pei and Melmed, 1997; Heaney et al., 1999; Zhang et al., 1999; Yu et al., 2000; Bernal et al., 2002; Wang et al., 2003; Boelaert et al., 2004; Hamid and Kakar, 2004; Hamid et al., 2005; Gillingwater et al., 2006). Pttg1 ${ }^{-/}$mice developed aberrations in cell cycle progression, hyperplasia in testis, and chromosomal breaks (Wang et al., 2001). In the nucleus, Pttg1 associates with p53, modulating its levels and function (Zhou et al., 2003; Hamid et al., 2005). We propose that a decrease of Pttg1 mRNA levels suppresses the onset of cell death or apoptosis in $\mathrm{Crb1}^{\mathrm{C} 249 \mathrm{~W} /-}$ and $\mathrm{Crb1}^{-/-}$retinas.

Downregulation of Pttg1 was identified in $\mathrm{Crb}^{\mathrm{C249W/-}}$ and 
verified in $\mathrm{Crb1}^{-1-}$ retinas. These data suggest that the extracellular domain of Crb1 influences Pttg1 transcript levels. Previously, the extracellular domain of fruit fly Crumbs was shown to function in prevention against light damage. Our data identified for the first time a putative function for the extracellular domain of mammalian Crb1. These data suggest that the transmembrane protein Crb1 functions in regulating Pttg1 transcription or RNA decay. The intracellular domains of Crb proteins are bound by Par6 (partitioning defective-6) and the MAGUK protein Pals1. Retinal Pals1 binds in vivo Crb1, Crb2, Crb3, Mpp3, Mupp1, and Veli3 (vertebrate lin-7 homolog 3) (Stohr et al., 2004; van de Pavert et al., 2004; Kantardzhieva et al., 2006; van Rossum et al., 2006). Other MAGUK proteins, such as calcium/calmodulindependent serine kinase, are known to participate in signaling from the plasma membrane to the nucleus (Hsueh et al., 2000). We hypothesize that not Crb1 itself but one of the intracellular interacting proteins (e.g., Pals1, Mpp3, and Veli3) might play a role in signaling to the nucleus or Pttg1 RNA decay complex. The Crb1 complex at the SAR is necessary for maintenance of adhesion between Müller glia cells and photoreceptors (van de Pavert et al., 2004). This adhesion is mediated by the cadherin/catenin complex at the adherens junction at the OLM. $\beta$-Catenin is known to signal between the plasma membrane, cytoplasm, and nucleus and is therefore a candidate mediator in signaling from Crb1 to Pttg1. The Pttg1 gene was shown to be regulated by the $\beta$-catenin/ternary complex factor pathway (Zhou et al., 2005). Lowered Pttg1 transcript levels in the two mutant Crb1 mouse strains may be an indirect effect. It is, for example, possible that inactivation of the extracellular sixth EGF domain of Crb1 causes a cellular response that initiates a yet unidentified biochemical cascade (e.g., the apoptosis, cell proliferation, or stress response machinery) that regulates Pttg1 transcription or RNA decay. We argue that this is less likely for the following reasons. (1) Control and mutant mice were exposed to low doses of white light $(3000$ lux) for a continuous period of $72 \mathrm{~h}$. The results of the microarray did not, however, indicate significant upregulation or downregulation (more than twofold) of a cascade of stress response, cell proliferation, or apoptosis genes in $\mathrm{Crb} 1^{\mathrm{C} 249 \mathrm{~W} /-}$ retinas. Even focally increased and relocalized immunostaining for GFAP in the mutant retina did not result in increased GFAP mRNA. (2) Whole $\mathrm{Crb1}^{-/-}$and $\mathrm{Crb}^{\mathrm{C} 249 \mathrm{~W} /-}$ retinas were isolated at a time point that no or little obvious retinal degeneration could be detected, minimizing the possibility of looking at secondary effects. (3) Both full ablation of Crb1 function and inactivation of the sixth EGF domain of Crb1 lead to deregulation of the Pttg1 transcript levels. (4) Lower levels of Pttg1 were not observed in light-exposed retinas of another mouse model with retinal folds $\left(M p p 4^{-/-}\right)$, indicating specificity for mutant Crb1 retinas. These data pinpoint a function for the extracellular domain of Crb1 in regulating Pttg1 transcript levels.

We detected significant downregulation of Pttg1 mRNA, but, using four different antibodies against Pttg1, specific Pttg1 proteins could not be detected in retinal lysates or in retina tissue sections. In forthcoming experiments, we will identify the components involved in the Crb1/Pttg1 signaling pathway and will examine the relevance of Pttg1 downregulation in retinal degeneration.

\section{References}

Aartsen WM, Kantardzhieva A, Klooster J, van Rossum AGSH, van de Pavert SA, Versteeg I, Cardozo BN, Tonagel F, Beck SC, Tanimoto N, Seeliger MW, Wijnholds J (2006) Mpp4 recruits Psd95 and Veli3 towards the photoreceptor synapse. Hum Mol Genet 15:1291-1302.
Akhmedov NB, Piriev NI, Chang B, Rapoport AL, Hawes NL, Nishina PM, Nusinowitz S, Heckenlively JR, Roderick TH, Kozak CA, Danciger M, Davisson MT, Farber DB (2000) A deletion in a photoreceptor-specific nuclear receptor mRNA causes retinal degeneration in the rd7 mouse. Proc Natl Acad Sci USA 97:5551-5556.

Bernal JA, Luna R, Espina A, Lazaro I, Ramos-Morales F, Romero F, Arias C, Silva A, Tortolero M, Pintor-Toro JA (2002) Human securin interacts with p53 and modulates p53-mediated transcriptional activity and apoptosis. Nat Genet 32:306-311.

Boelaert K, Yu R, Tannahill LA, Stratford AL, Khanim FL, Eggo MC, Moore JS, Young LS, Gittoes NJ, Franklyn JA, Melmed S, McCabe CJ (2004) PTTG's C-terminal PXXP motifs modulate critical cellular processes in vitro. J Mol Endocrinol 33:663-677.

Cremers FP, Van Den Hurk JA, den Hollander AI (2002) Molecular genetics of Leber congenital amaurosis. Hum Mol Genet 11:1169-1176.

den Hollander AI, Ghiani M, de Kok YJ, Wijnholds J, Ballabio A, Cremers FP, Broccoli V (2002) Isolation of Crb1, a mouse homologue of Drosophila crumbs, and analysis of its expression pattern in eye and brain. Mech Dev 110:203-207.

den Hollander AI, Davis J, Van Der Velde-Visser SD, Zonneveld MN, Pierrottet CO, Koenekoop RK, Kellner U, van den Born LI, Heckenlively JR, Hoyng CB, Handford PA, Roepman R, Cremers FP (2004) CRB1 mutation spectrum in inherited retinal dystrophies. Hum Mutat 24:355-369.

Dijk F, Kraal-Muller E, Kamphuis W (2004) Ischemia-induced changes of AMPA-type glutamate receptor subunit expression pattern in the rat retina: a real-time quantitative PCR study. Invest Ophthalmol Vis Sci 45:330-341.

Gillingwater TH, Wishart TM, Chen PE, Haley JE, Robertson K, MacDonald SH, Middleton S, Wawrowski K, Shipston MJ, Melmed S, Wyllie DJ, Skehel PA, Coleman MP, Ribchester RR (2006) The neuroprotective WldS gene regulates expression of PTTG1 and erythroid differentiation regulator 1-like gene in mice and human cells. Hum Mol Genet 15:625-635.

Hamid T, Kakar SS (2004) PTTG/securin activates expression of p53 and modulates its function. Mol Cancer 3:18.

Hamid T, Malik MT, Kakar SS (2005) Ectopic expression of PTTG1/securin promotes tumorigenesis in human embryonic kidney cells. Mol Cancer $4: 3$.

Heaney AP, Horwitz GA, Wang Z, Singson R, Melmed S (1999) Early involvement of estrogen-induced pituitary tumor transforming gene and fibroblast growth factor expression in prolactinoma pathogenesis. Nat Med 5:1317-1321.

Hsueh YP, Wang TF, Yang FC, Sheng M (2000) Nuclear translocation and transcription regulation by the membrane-associated guanylate kinase CASK/LIN-2. Nature 404:298-302.

Johnson K, Grawe F, Grzeschik N, Knust E (2002) Drosophila crumbs is required to inhibit light-induced photoreceptor degeneration. Curr Biol 12:1675-1680.

Kantardzhieva A, Gosens I, Alexeeva S, Punte IM, Versteeg I, Krieger E, Neefjes-Mol CA, den Hollander AI, Letteboer SJF, Klooster J, Cremers FPM, Roepman R, Wijnholds J (2005) MPP5 recruits MPP4 to the CRB1 complex in photoreceptors. Invest Ophthalmol Vis Sci 46:2192-2201.

Kantardzhieva A, Alexeeva S, Versteeg I, Wijnholds J (2006) MPP3 is recruited to the MPP5 protein scaffold at the retinal outer limiting membrane. FEBS J 273:1152-1165.

Mehalow AK, Kameya S, Smith RS, Hawes NL, Denegre JM, Young JA, Bechtold L, Haider NB, Tepass U, Heckenlively JR, Chang B, Naggert JK, Nishina PM (2003) CRB1 is essential for external limiting membrane integrity and photoreceptor morphogenesis in the mammalian retina. Hum Mol Genet 12:2179-2189.

Meuleman J, Van de Pavert SA, Wijnholds J (2004) Crumbs homologue 1 in polarity and blindness. Biochem Soc Trans 32:828-831.

Pei L, Melmed S (1997) Isolation and characterization of a pituitary tumortransforming gene (PTTG). Mol Endocrinol 11:433-441.

Pellikka M, Tanentzapf G, Pinto M, Smith C, McGlade CJ, Ready DF, Tepass U (2002) Crumbs, the Drosophila homologue of human CRB1/RP12, is essential for photoreceptor morphogenesis. Nature 416:143-149.

Rattner A, Nathans J (2005) The genomic response to retinal disease and injury: evidence for endothelin signaling from photoreceptors to glia. J Neurosci 25:4540-4549.

Roh MH, Makarova O, Liu CJ, Shin K, Lee S, Laurinec S, Goyal M, Wiggins R, 
Margolis B (2002) The Maguk protein, Pals1, functions as an adapter, linking mammalian homologues of Crumbs and Discs Lost. J Cell Biol 157:161-172.

Seeliger MW, Grimm C, Stahlberg F, Friedburg C, Jaissle G, Zrenner E, Guo H, Reme CE, Humphries P, Hofmann F, Biel M, Fariss RN, Redmond TM, Wenzel A (2001) New views on RPE65 deficiency: the rod system is the source of vision in a mouse model of Leber congenital amaurosis. Nat Genet 29:70-74.

Seeliger MW, Beck SC, Pereyra-Munoz N, Dangel S, Tsai JY, Luhmann UF, Van de Pavert SA, Wijnholds J, Samardzija M, Wenzel A, Zrenner E, Narfstrom K, Fahl E, Tanimoto N, Acar N, Tonagel F (2005) In vivo confocal imaging of the retina in animal models using scanning laser ophthalmoscopy. Vision Res 45:3512-3519.

Stohr H, Molday LL, Molday RS, Weber BH, Biedermann B, Reichenbach A, Kramer F (2004) Membrane-associated guanylate kinase proteins MPP4 and MPP5 associate with Veli3 at distinct intercellular junctions of the neurosensory retina. J Comp Neurol 481:31-41.

Tikellis C, Cooper ME, Twigg S, Burns WC, Tolcos M (2004) Connective tissue growth factor is up-regulated in the diabetic retina: amelioration by angiotensin-converting enzyme inhibition. Endocrinology 145:860-866.

van de Pavert SA, Kantardzhieva A, Malysheva A, Meuleman J, Versteeg I, Levelt C, Klooster J, Geiger S, Seeliger MW, Rashbass P, Le Bivic A, Wijnholds J (2004) Crumbs homologue 1 is required for maintenance of photoreceptor cell polarization and adhesion during light exposure. J Cell Sci 117:4169-4177.

Vandesompele J, De Preter K, Pattyn F, Poppe B, Van Roy N, De Paepe A, Speleman F (2002) Accurate normalization of real-time quantitative
RT-PCR data by geometric averaging of multiple internal control genes. Genome Biol 3:34.1-34.11.

van Rossum AG, Aartsen WM, Meuleman J, Klooster J, Malysheva A, Versteeg I, Arsanto J-P, Le Bivic A, Wijnholds J (2006) Pals1/Mpp5 is required for correct localization of Crb1 at the sub-apical region in polarized Müller glia cells. Hum Mol Genet 15:2659-2672.

Wang Z, Yu R, Melmed S (2001) Mice lacking pituitary tumor transforming gene show testicular and splenic hypoplasia, thymic hyperplasia, thrombocytopenia, aberrant cell cycle progression, and premature centromere division. Mol Endocrinol 15:1870-1879.

Wang Z, Moro E, Kovacs K, Yu R, Melmed S (2003) Pituitary tumor transforming gene-null male mice exhibit impaired pancreatic beta cell proliferation and diabetes. Proc Natl Acad Sci USA 100:3428-3432.

Yu R, Heaney AP, Lu W, Chen J, Melmed S (2000) Pituitary tumor transforming gene causes aneuploidy and p53-dependent and p53independent apoptosis. J Biol Chem 275:36502-36505.

Zhang X, Horwitz GA, Prezant TR, Valentini A, Nakashima M, Bronstein MD, Melmed S (1999) Structure, expression, and function of human pituitary tumor-transforming gene (PTTG). Mol Endocrinol 13:156-166.

Zhou C, Liu S, Zhou X, Xue L, Quan L, Lu N, Zhang G, Bai J, Wang Y, Liu Z, Zhan Q, Zhu H, Xu N (2005) Overexpression of human pituitary tumor transforming gene (hPTTG), is regulated by beta-catenin/TCF pathway in human esophageal squamous cell carcinoma. Int $\mathrm{J}$ Cancer 113:891-898.

Zhou Y, Mehta KR, Choi AP, Scolavino S, Zhang X (2003) DNA damageinduced inhibition of securin expression is mediated by p53. J Biol Chem 278:462-470 